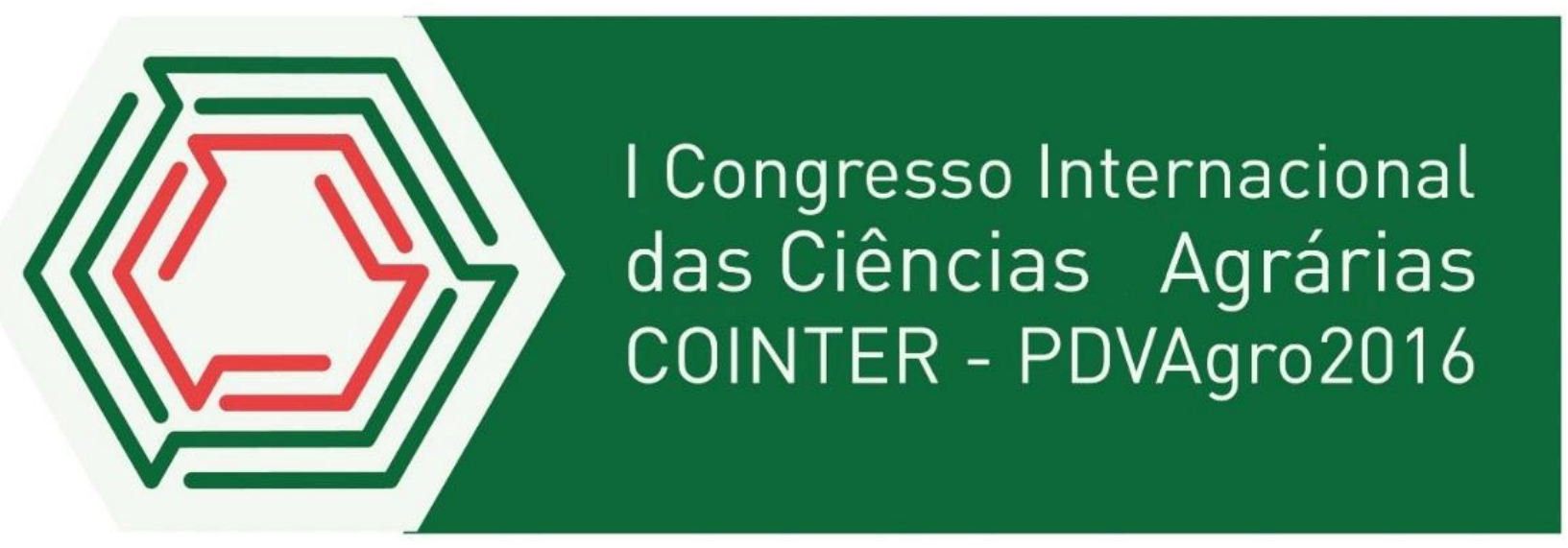

\title{
SABORES DA CAATINGA: OFICINA DE VALORIZAÇÃO DE NOSSO BIOMA
}

Apresentação: Relato de Experiência

Ivanice da Silva Santos ${ }^{1}$; Giuliane Karen de Araújo Silva ${ }^{1}$; Anny Kelly Vasconcelos. de O. Lima $^{2}$; Cassius Ricardo Santana da Silva ${ }^{3}$; Frederico Campos Pereira ${ }^{3}$

\section{Introdução}

A palma forrageira (Opuntia fícus indica) constitui importante cultura agrícola em zonas áridas e semiáridas de diversos países, principalmente na região Nordeste do Brasil. O seu cultivo é utilizado para diversos fins, sendo mais requisitado para a alimentação animal. Porém, atualmente estar se dando um enfoque maior a utilização desse espécime na alimentação humana. Os brotos, ou raquetes da palma são usados em preparos culinários assumindo o papel de verdura, e o fruto além de poder ser beneficiado em doces, compotas, caldas, são comercializados a valores exorbitantes em outras regiões brasileiras, o que demonstra o grande potencial econômico dessa cultura. $\mathrm{O}$ fruto da palma contém mais carboidratos, fibras e cálcio do que a laranja, por exemplo. Dessa forma, assume importante papel quando se fala de segurança alimentar, principalmente no semiárido brasileiro, onde as demais culturas sofrem com períodos prolongados de seca. (LOPES, 2012).

\section{Relato de Experiência}

O projeto Sabores da Caatinga têm como objetivo valorizar dentro da cultura gastronômica da região, á aceitabilidade, ampliação de saberes e segurança alimentar, tendo como ingrediente principal as cactáceas, destacando-se entre elas a palma forrageira (Opuntia ficus-indica) como base para um grande número de receitas nutricionalmente saudáveis (SILVA et al, 2015). No mês de setembro do corrente ano o projeto foi convidado para ser uma das atrações da II Semana de Agroecologia do Instituto Federal de Educação Ciência e Tecnologia do Ceará (IFCE) campus Limoeiro do Norte. A oficina ocorreu no dia 23 de setembro, pela manhã, no laboratório de

\footnotetext{
${ }^{1}$ Discentes de Agroecologia, IFPB, campus Picuí, ivanicebio@gmail.com;

${ }^{2}$ Bolsista DCR IFPB/FAPESQ/CNPQ; annykellyv@hotmail.com

${ }^{3}$ Professores do Curso de Agroecologia IFPB Campus Picuí, fredcampos2000@yahoo.com.br
} 
beneficiamento de frutos do próprio campus, e contou com a participação de 20 alunos, do próprio campus e de outras instituições, divididos entre os cursos das Ciências Agrárias, Tecnologia em Alimentos e Nutrição.

Durante a oficina apresentamos aos alunos receitas novas como Risoto de frango com cubinhos de palma, Suco mix que contém maracujá, ou qualquer outra fruta de preferência, e a polpa feita previamente da raquete da palma, além do Beijinho elaborado com a polpa do fruto da palma, creme de leite, leite condensado e coco ralado. Após a apresentação, elaboração e degustação das receitas acima citadas propomos aos alunos a sua divisão em dois grupos, os quais a partir de ingredientes que disponibilizamos pudessem colocar em prática o que aprenderam e desenvolverem novas receitas. (Figura 1).

Imagem 1 - Desenvolvimento das receitas à base de palma forrageira. Fonte própria

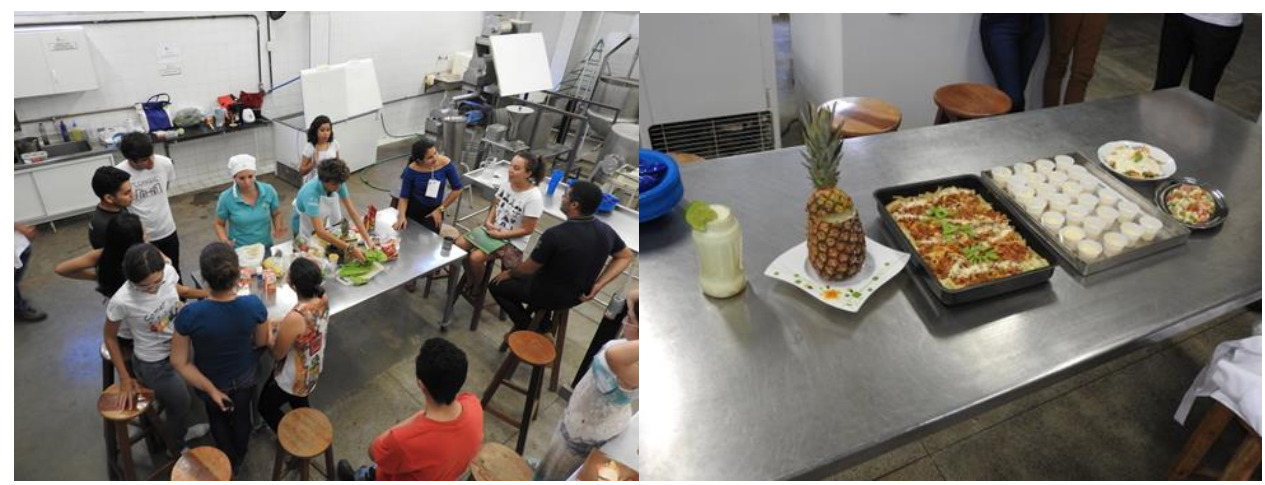

A experiência rendeu excelentes resultados, os dois grupos saíram vencedores e o projeto com receitas novas para sua vasta lista. Foram elaborados, molho para macarronada, batida do fruto da palma, mousse com o fruto da palma e maracujá, além disso, um dos grupos provou que é possível a palma assumir o papel de ingrediente principal e não apenas um complemento, desenvolveram macarrão a partir da raquete da palma cortada em tirinhas e apenas fervida.

\section{Considerações Finais}

A oficina ministrada pela equipe dos Sabores da Caatinga (NEA) possibilitou a socialização de áreas diversas, mas que puderam e encontraram juntas novas alternativas alimentares viáveis para a palma. No final os resultados surpreenderam pela simplicidade e ousadia, além da interação entre ministrantes e alunos ter sido ímpar. Obtivemos além de novas receitas a certeza da importância e viabilidade de se trabalhar cada vez mais as riquezas florísticas do semiárido. 


\section{Referências}

LOPES, Edson Batista. Palma forrageira: cultivo, uso atual e perspectivas de utilização no Semiárido nordestino. João Pessoa: EMEPA, PB, 2012.

SILVA, G.K.A; et al. Sabores da Caatinga e Slow Food: o prazer da alimentação regional. In: 